\title{
Discriminative and Predictive Ability of Physical Performance Measures in Identifying Fall Risk among Older Adults
}

(Keupayaan Ramalan dan Diskriminasi Ujian Prestasi Fizikal bagi Mengenal Pasti Risiko Jatuh dalam Kalangan Warga Emas di Malaysia)

\author{
Zunaidah Abu Samah, Devinder Kaur AjIT SingH*, Resshaya Roobini Murukesu, SuZana ShaHar, \\ NOR AZLIN MOHD NORDIN, MOHD AZAHADI OMAR \& CHIN AI-VYRN
}

\begin{abstract}
Falls are a public health concern among older adults. There is a need to take significant measures such as screening for the risk of a fall as a means of prevention and management. A cross-sectional study was conducted to determine discriminative and predictive ability of physical performance measures in identifying the risk of fall among Malaysian community dwelling older adults. Three hundred twenty-five Malaysian community dwelling older adults aged 60 years and above (67.67 \pm 5.5 years) participated in this study. This study was a part of a larger longitudinal study 'LRGS TUA'. Physiological Profile Assessment (PPA), a comprehensive tool for quantifying risk of fall was used as a standard measure of comparison to 6 Meter Gait Speed (GS), Timed Up and Go (TUG) and Walking While Talking (WWT) tests to establish discriminative and predictive ability. Participants recorded incidence of falls in a 'falls diary' over a span of six months. To determine the optimum cut off scores of the test identified to classify fall risk, receiver operator curves $(R O C)$ were used and its sensitivity and specificity were calculated. A significant mean difference between fallers and non-fallers was demonstrated only with TUG test $(\mathrm{p}<0.05)$. TUG test cut off score in discriminating older adults at risk of fall was established at eight seconds, with a sensitivity and specificity of $83.95 \%$ and $32.4 \%$, respectively, in this study. Eighty-four percent older adults who experienced a fall in our study were identified to be at risk of fall when screened using this TUG cut off score. Our study results suggested TUG test to be an optimal screening tool for risk of fall among community dwelling older adults.
\end{abstract}

Keywords: Aging; community dwelling; falls; geriatrics; risk assessment

\section{ABSTRAK}

Masalah jatuh adalah salah satu kemelut kesihatan awam dalam kalangan warga emas. Langkah pencegahan seperti pemeriksaan risiko jatuh diperlukan untuk menangani masalah ini. Tujuan kajian kami adalah untuk menentukan kesahan ramalan dan diskriminasi ujian prestasi fizikal dalam mengenal pasti risiko jatuh dalam kalangan warga emas yang tinggal di komuniti. Sejumlah 325 warga emas Malaysia dalam komuniti yang berusia 60 tahun ke atas (min umur dan piawaian sisihan: 67.67 5.5 tahun) telah direkrut melalui persampelan rawak bagi menyertai kajian hirisan lintang ini. Kajian ini adalah sebahagian daripada kajian longitud 'LRGS TUA'. Penilaian profil psikologi (PPA), ujian komprehensif untuk mengesan risiko jatuh telah digunakan sebagai pengukur piawai berbanding ujian kelajuan pergerakan 6 meter (GS), masa bangun dan pergi (TUG) dan berjalan sambil bercakap (WWT) untuk menentukan keupayaan diskriminasi dan kesahan ramalan. Para peserta mencatatkan insiden jatuh dalam 'diari jatuh'sepanjang tempoh 6 bulan. Bagi menentukan titik penggal yang optimum bagi ujian yang dikenal pasti untuk mengelaskan risiko jatuh, lengkung pengoperasi penerima (ROC) telah digunakan dan nilai kesensitifan dan kekhususan telah dikira. Ujian TUG dikenal pasti sebagai ujian prestasi fizikal yang mampu menunjukkan perbezaan yang signifikan antara warga emas yang pernah mengalami insiden jatuh dan yang tidak $(\mathrm{p}<0.05)$. Skor titik potong ujian TUG dalam mendiskriminasi warga emas yang berisiko jatuh adalah lapan saat dengan kesensitifan dan kekhususan sebanyak $83.95 \%$ dan 32.4\%. Berdasarkan skor titik potong ujian TUG ini, didapati bahawa $84 \%$ warga emas dalam kajian ini yang telah mengalami insiden jatuh dikesan sebagai mempunyai risiko jatuh. Keputusan kajian kami mencadangkan Ujian TUG sebagai ujian saringan yang paling sesuai untuk menyaring risiko jatuh dalam kalangan warga emas dalam komuniti.

Kata kunci: Dalam komuniti; geriatrik; insiden jatuh; penilaian risiko; warga emas

\section{INTRODUCTION}

The ageing population is increasing parallel to increasing life expectancy, resulting in increased susceptibility to health problems such as the risk of fall (Sahin \& Erkai
2016). Characterized as a 'geriatric syndrome', falls have become an epidemically devastating and growing public health concern amongst health practitioner worldwide (Lee et al. 2013). 
The global prevalence of falls among community dwelling older adults ranges between 28 and $35 \%$ (Williams et al. 2015). In the Malaysian context, prevalence of falls among community dwelling older adults is between 15-28 \% (Ibrahim et al. 2017a, 2017b; Rizawati \& Mas Ayu 2008). The consequences of falls are debilitating and are commonly associated with loss of independence, injuries, disability and death. In addition falls often result in premature nursing home admission, requiring personal and acute long-term health care, leading to social, physical, financial and care taker burden (Lee et al. 2013).

Falls have been reported to be prevalent among institutionalized older adults, stemming from reduced physical performance (Csapo et al. 2009; Makhlouf \& Ayoub 2000). However, falls have been found to occur outdoors and at a maximal activity levels among independent older adults (Dhargave \& Sendhilkumar 2016). In the context of community dwelling older adults, falls and its consequences can be prevented with early screening (Lee et al. 2013). A wide range of clinical performance-based measurement tools are available in the clinical settings aimed to screen for the risk of fall, focusing on different domains such as balance, strength, physiological impairments and functional physical performance (Singh et al. 2015). Chang et al. (2004) reported the efficacy of multiple component fall risk assessments, namely the 'Falls Prevention Program' as a means of falls screening and management. A significant correlation $(p<0.01 ; r=0.23-0.33)$ has been found between physical performance monitoring tools and risk of fall; specifically, those assessing balance and mobility functions among older adults (Singh et al. 2015).

Although outcome measures used to determine the risk of fall are currently available, there is an evident lack of literature illuminating the ability of a single physical performance measure to robustly predict fall risk. Hence, the purpose of this study were to determine the discriminative and predictive ability of three different physical performance monitoring tools in identifying risk of fall and to determine the most suitable physical performance screening tool for fall risk among community dwelling older adults.

\section{METHODS}

A total of 325 community dwelling older adults aged 60 and above (180 women, 145 men), ranging between 60 and 89 years old (mean age: $67.64 \pm 5.5$ years) participated in this cross-sectional study. Participants were recruited via multistage random sampling; as a part of a longitudinal study 'LRGS TUA - Neuroprotective Model for Healthy Longevity among Malaysian older adults'. Data was collected over a span of 12 months of May 2013 - April 2014 across 9 districts within the state of Selangor reported to be most dense in population of community dwelling older adults as reported by the Department of Statistics (2010). An initial screening of participants was done prior to recruitment and excluded older adults with communication difficulty, acute illnesses, fractured extremities, diagnosed with vestibular disorder, severe hearing and/or vision impairments, had undergone hip or knee joint replacement surgery, lower limb prosthesis as well as severe musculoskeletal and/or neurological disorders. Cognitive function of the participants was also screened, using the Mini Mental State Examination (MMSE) (inclusion score: $\geq 21 / 30$ ) and Geriatric Depression Scale (GDS) (inclusion score: $\leq 4 / 15$ ) (Borson et al. 2003; Shahar et al.2015). Participation in this study was voluntary with informed written consent.

The operative definition of falls in our study was 'any event that results in a bodily change that forces an individual to inadvertently land on the ground or a lower level', other than because of a violent strike, loss of consciousness, sudden onset of paralysis or epileptic seizure, as defined by the World Health Organization (2008) and Kellogg International Work Group (1987) on falls prevention among older adults.

\section{FALL RISK ASSESSMENT}

The Physical Profile Assessment (PPA) is a comprehensive tool for quantifying risk of fall (fallers and non-fallers). The PPA was used as a standard measure of comparison against three physical performance measures, namely the 6 Meter Gait Speed (GS), Timed Up and Go (TUG) and Walking While Talking (WWT) test to establish their discriminative and predictive capabilities. These tests were conducted by trained physiotherapists recruited as research assistants for this study.

\section{PHYSIOLOGICAL PROFILE ASSESSMENT (PPA)}

Fall risk was determined using the short version PPA. The PPA is a valid and reliable (ICC 0.50-0.97) fall risk assessment which includes five physiological domains (Lord et al. 2003). Visual contrast sensitivity, peripheral sensation, knee strength, reaction time and postural sway were assessed using the Melbourne Edges Test (MET), knee joint positioning, a spring gauge, a hand held electronic timer and a sway meter at waist level, respectively. Participants were then categorized into two groups: high and low risk of fall based on the PPA risk score (Lord et al. 2003; Whitney et al. 2005).

\section{METER GAIT SPEED TEST (GS)}

Participants walked $10 \mathrm{~m}$ on flat ground at their comfortable walking pace. The first and last $2 \mathrm{~m}$ across the $10 \mathrm{~m}$ distance were marked and counted as gait acceleration and deceleration period; hence time was only taken after the $2 \mathrm{~m}$ mark and stopped at the $8 \mathrm{~m}$ mark which totals to $6 \mathrm{~m}$ of uniformed gait speed. The use of assistive device was allowed if required by the participants. Gait speed was calculated by dividing the $6 \mathrm{~m}$ to the time taken in seconds. The average speed of the three trials was taken as the gait speed in meters per second (Novaes et al. 2011). The validity and reliability of the 6MWT as an assessment 
of walking ability has been established in a study by Lam et al. (2010). The ICC coefficients of test-retest and intertester reliability were reported as 0.99 and 0.98 , respectively (Lam et al. 2010).

\section{TIME UP AND GO TEST (TUG)}

The TUG began with the participant rising from a standard arm chair, walking along $3 \mathrm{~m}$ as marked across a flat surface, making a complete turn to return and sitting back down on the chair at comfortable walking pace. Participants were required to wear their daily use footwear for the test. Participants were to independently carry out the test and any use of walking assistive device was documented (Mathias et al. 1986). The TUG is a reliable outcome measure screening the risk of fall with an ICC of 0.98 among community dwelling older adults (ShumwayCook et al. 2000).

\section{WALKING WHILE TALKING TEST (WWT)}

In this test, participants counted backwards from number thirty while walking a distance of $10 \mathrm{~m}$ along a flat surface. Participants were to execute walking and talking simultaneously without prioritizing either. Counting of the numbers could be spoken in the language that the participant was most comfortable with; which were either English, Malay, Chinese or Tamil dialects. The test score was calculated by dividing the walking distance over time taken to complete the test and mistakes made while counting was not corrected (Verghese et al.2002). Criterion validity and adequate reliability $(r=0.60)$ for the WWT test among community dwelling older adults without dementia has been established by Verghese et al. (2002).

\section{PROSPECTIVE FALLS ASSESSMENT}

Participants were provided with a pre-addressed, postage paid 'falls diary' to record any incidence of falls 6 months after the initial assessment. The diaries were required to be returned to the researcher at the end of the sixth month. Monthly follow up via phone calls were made to each participant to reduce the chances of recall bias. The mail-in reporting and follow up phone calls approach was selected as it is one of the most rigorous methods of prospective monitoring of falls among older adults (Lord et al. 2003).

\section{STATISTICAL ANALYSIS}

Data was analyzed using the IBM Statistical Package for the Social Sciences (SPSS) version 20. The statistical significance level was set at $p<0.05$. Participants were categorized into fallers and non-fallers groups based on prospective fall information. The test that has a significant mean difference to discriminate between these two groups was identified. Receiver operator curves (ROC) were used to determine the optimum cut off scores to classify fall risk and its sensitivity and specificity were calculated for the identified test.

\section{RESULTS}

A total of 325 older adults within the state of Selangor participated in this study (Figure 1). Table 1 summarizes

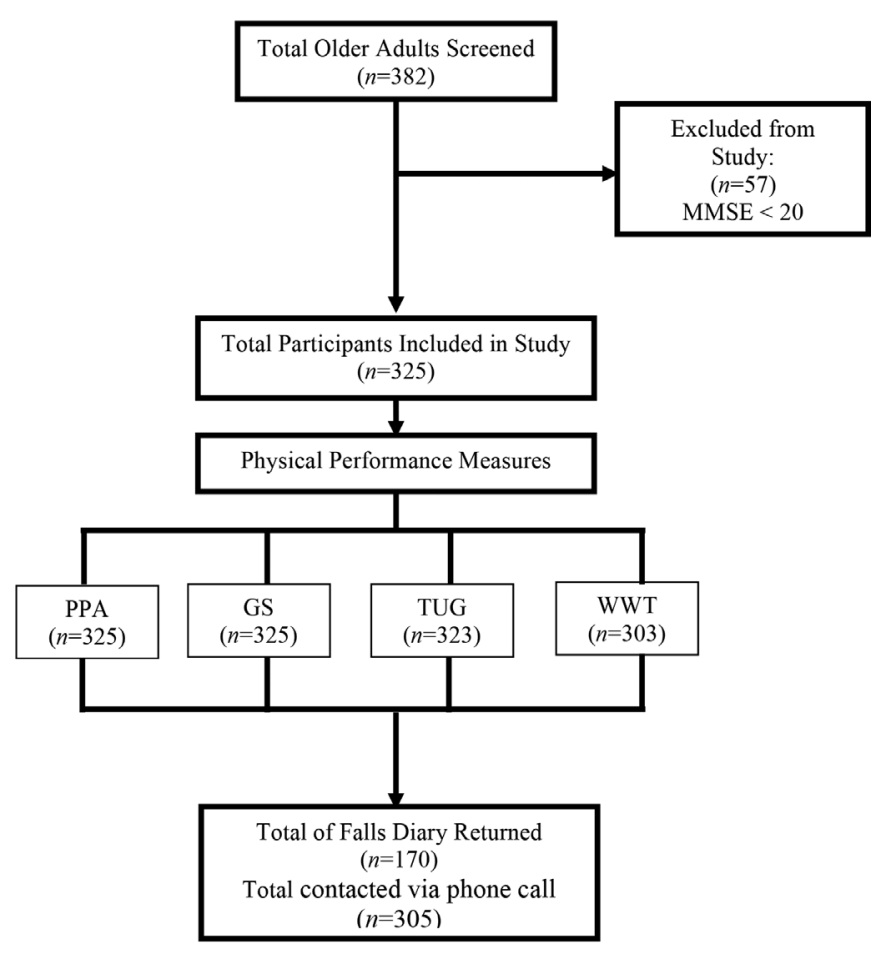

FIGURE 1. Summary of participants in the study 
TABLE 1. Summary feedback of falls diary after 6 months follow up

\begin{tabular}{lrr}
\hline & Frequency (n) & $\%$ \\
\hline Number of participants recruited & 325 & $100 \%$ \\
Number of falls diary given was based on number of participants recruited & 325 & $100 \%$ \\
Number of participants contacted via phone call & 305 & $93.8 \%$ \\
Number of falls diary returned & 170 & $85.7 \%$ \\
Number of event of falls reported via phone calls & $26.5 \%$ & 81 \\
\hline
\end{tabular}

the response rate of participants in this study at the end of 6-month prospective falls monitoring based on the falls diary and phone call follow ups. More than half (55.8\%, $n=170$ ) of the distributed falls diary were returned and 93.8\% ( $n=305)$ of the participants were reachable via phone call for follow up. The drop out percentage of this study was low, at $6.2 \%$ due to non-response to follow up phone calls.

The total percentage of fallers reported within the course of this study from the time of initial assessment was $26.6 \%$ (30 men, 51 female) with a mean age of 68.2 \pm 5.9 years and non-fallers at $73.4 \%$ (104 men, 120 female) with mean age of $67.32 \pm 5.3$ years. Socio-demographic details and physical performance test scores of participants were categorized as 'high risk' or 'low risk' of falls based on PPA scores, as summarized in Table 2. Older adults with 'high risk falls' were found to be older than those with 'low risk' $(p<0.05)$. Between the three physical performance tests, only TUG test scores showed a significant difference between the fall risk groups $(p<0.05)$. Older adults who were categorized as 'high risk' of falls took a longer time to complete the TUG test (9.35 seconds (IQR: 6.40-17.55) as compared to those with low risk of fall (8.94 seconds (IQR: 4.8-18.05).

In Table 3, participants' socio-demographic characteristics and physical performance test scores based on the follow up, 6 months prospectively from initial assessment is summarized. Older adults were categorized as 'fallers' and 'non-fallers' based on self-reported incidence of falls. Out of a total of 305 older adults (134 men, 171 women), 81 older adults were categorized as 'fallers' and 224 were 'non-fallers'. Only the TUG test showed a significant difference between faller and nonfaller groups $(p<0.05)$.

A receiver operating characteristics (ROC) curve was generated to interpret the sensitivity and specificity of the TUG test $(p<0.05)$ as illustrated in Figure 2. Following which, the suitable cut off scores of the TUG test to determine an increased risk of fall is tabulated in Table 4. TUG cut of score of more than eight seconds with a sensitivity of $83.95 \% \%$ (CI: 74.1-91.2) and specificity of $32.43 \%$ (CI: 26.3-39.0) was identified. The likelihood ratio for negative (LR-) and positive (LR+) results were $31.2 \%$ (CI: 25.1-37.8) and 84.7\% (CI: 75.3-91.6), respectively.

\section{DISCUSSION}

The aim of this study was to determine the discriminative and predictive ability of physical performance measures in identifying the risk of fall among Malaysian community dwelling older adults, namely, Timed Up and Go test (TUG), Gait Speed test (GS), Walk While Talking test (WWT) in correlation to the Physiological Profile Approach (PPA). The results of this study showed the TUG test to be the only robust physical performance test in screening for fall risk in community dwelling older adults in our study.

Falls prevalence among community dwelling older adults monitored prospectively in our study was $26.6 \%$. This prevalence rate is close to global reports of one third older adults experiencing a fall annually. Contrarily, this

TABLE 2. Demographic characteristics, GS, TUG and WWT scores for low and high risk of fall groups

\begin{tabular}{lcccc}
\hline & $\begin{array}{c}\text { Low falls risk } \\
n=285\end{array}$ & $\begin{array}{c}\text { High falls risk } \\
n=40\end{array}$ & $\begin{array}{c}\text { Total sample } \\
n=325\end{array}$ & P value \\
\hline Age (SD) & $67.25(5.4)$ & $70.43(5.3)$ & $67.64(5.5)$ & $<0.001^{*}$ \\
Gender & & & 0.33 \\
$\quad$ Men (\%) & $130(89.7 \%)$ & $15(10.3 \%)$ & 145 & \\
$\quad$ Women (\%) & $155(86.1)$ & $25(13.9 \%)$ & 180 & 0.20 \\
Gait speed (m/s): mean (SD) & $1.06(0.25)$ & $1.01(0.25)$ & $1.05(0.25)$ & $<0.001^{*}$ \\
TUG (s): median (IQR) & $8.94(4.8-18.05)$ & $9.35(6.40-17.55)$ & $9.1(4.8-18.05)$ & 0.12 \\
WWT (m/s): median (IQR) & $0.79(0.23)$ & $0.74(0.24)$ & $0.77(0.23)$ & $<0.001^{*}$ \\
PPA score: median (IQR) & $0.47(-16.54-2.17)$ & $1.53(1.00)$ & $0.61(-16.54-2.24)$ & \\
\hline
\end{tabular}


TABLE 3. Demographic characteristics, GS, TUG and WWT scores after 6 months prospectively based on falls diary $(n=305)$

\begin{tabular}{|c|c|c|c|c|}
\hline & $\begin{array}{c}\text { Fallers } \\
n=81(26.6 \%)\end{array}$ & $\begin{array}{c}\text { Non-fallers } \\
n=224(73.4 \%)\end{array}$ & $\begin{array}{c}\text { Total sample } \\
\mathrm{N}=305\end{array}$ & P-value \\
\hline Age (SD) & $68.2(5.9)$ & $67.32(5.3)$ & $67.55(5.5)$ & 0.22 \\
\hline $\begin{array}{l}\text { Gender } \\
\text { Men: } n(\%) \\
\text { Women: } n(\%)\end{array}$ & $\begin{array}{l}30(37) \\
51(63)\end{array}$ & $\begin{array}{l}104(46.4) \\
120(53.6)\end{array}$ & $\begin{array}{l}134(43.9) \\
171(56.1)\end{array}$ & 0.14 \\
\hline $\begin{array}{l}\text { Education level } \\
\quad \text { No formal education } \\
\text { Formal education: } \\
\quad 1-6 \text { years } \\
\text { Formal education: }>7 \text { years }\end{array}$ & $\begin{array}{c}20(24.7) \\
30(37)\end{array}$ & $\begin{array}{l}39(17.4) \\
61(27.2) \\
124(55.4)\end{array}$ & $\begin{array}{c}59(1.3) \\
91 .(29.8) \\
155(50.8)\end{array}$ & $<0.01 *$ \\
\hline \multicolumn{5}{|c|}{ Physical Performance Measures } \\
\hline $\begin{array}{l}\mathrm{GS}(\mathrm{m} / \mathrm{s}): \\
\quad \text { mean }(\mathrm{SD})\end{array}$ & $1.06(0.25)$ & $1.01(0.25)$ & $1.05(0.25)$ & 0.20 \\
\hline $\begin{array}{l}\text { TUG }(\mathrm{s}): \\
\text { median (IQR) }\end{array}$ & $8.94(4.8-18.05)$ & $9.35(6.40-17.55)$ & $9.1(4.8-18.05)$ & $0.03 *$ \\
\hline WWT (m/s): median (IQR) & $0.79(0.23)$ & $0.74(0.24)$ & $0.77(0.23)$ & 0.12 \\
\hline PPA score: median (IQR) & $0.47(-16.54-2.17)$ & $1.53(1.00)$ & $0.61(-16.54-2.24)$ & $<0.001 *$ \\
\hline
\end{tabular}

$p<0.05^{*}$

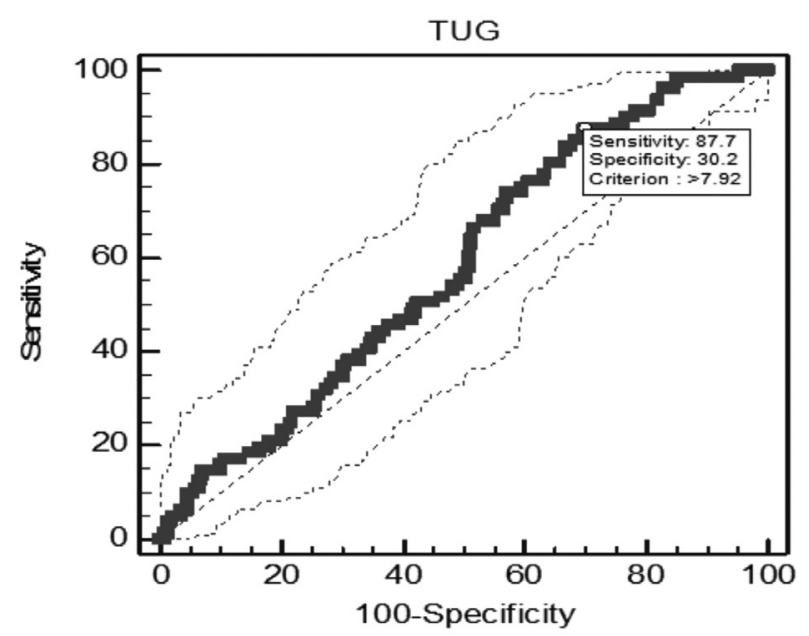

FIGURE 2. ROC analyses for discriminative and predictive validity of the TUG test

falls prevalence finding is higher than the ones reported $(15-18 \%)$ in our team's earlier cross-sectional studies among Malaysian represented community dwelling older adults (Ibrahim et al. 2017a, 2017b). Approximately 12\% of the participants were considered at 'high risk of fall'. These findings are almost identical to that of Singh et al. (2015) whereby $13 \%$ of community dwelling older adults were found to be at high risk of fall when screened using the PPA.

Socio-demographically, older adults categorized as 'high risk' of falls in our study had a higher mean age compared to 'low risk' of falls group $(p<0.001)$. However, ageing on its own is not a contributor of falls, rather the age-related changes in terms of physiology predispose older adults to falls as well as frailty (Masud \& Morris 2001). In terms of gender, higher percentage of older women compared to men were categorized as 'high risk of fall' in this study. This is in accordance to that reported in a study conducted among Japanese community dwelling older adults whereby older women were at higher risk of fall than men (Ishimoto et al. 2009).

There is currently no established gold standard physical performance test aimed at screening risk of fall among older adults. PPA, a comprehensive physical performance test addresses the vital physiological domains required to maintain an individual's ability to prevent a fall. Hence, the use of the PPA as a standard measure against the three other physical performance tests to determine their predictive abilities in our study is justified. Moreover, PPA score in our study showed a significant $(p<0.001)$ difference between older adults with and without falls, when classified as suggested by Whitney et al. (2005).

The comparison between TUG, GS, WWT against PPA tests was done to determine the test with the best discriminative and predictive value for the purpose of screening community dwelling older adults for the risk of fall. In this study, it was found that only the mean score of the TUG test illustrated a significant mean difference between older adults who had incidence of falls and those who did not $(p<0.05)$. GS and WwT on the other hand did not show to have a significant difference in mean score between these two groups of older adults $(p>0.05)$. It is suggested that the cutoff point in screening for risks should only be determined if and when there is a significant difference between the two groups of the particular study (Chiu et al. 2003).

Our study findings denoted eight seconds as the cut off score with a sensitivity and specificity of $83.95 \%$ and 
TABLE 4. Metrics of individual scores of the TUG test for classifying increased risk of fall

\begin{tabular}{ccccccccccc}
\hline $\begin{array}{c}\text { Cut Off } \\
(\mathrm{sec})\end{array}$ & $\begin{array}{c}\text { Sensitivity } \\
(\%)\end{array}$ & Specificity $(\%)$ & LR+ & LR- & PPV & NPV & $\begin{array}{c}\text { True+ } \\
(\mathrm{n})\end{array}$ & $\begin{array}{c}\text { False+ } \\
(\mathrm{n})\end{array}$ & $\begin{array}{c}\text { True- } \\
(\mathrm{n})\end{array}$ & $\begin{array}{c}\text { False- } \\
(\mathrm{n})\end{array}$ \\
\hline $8^{*}$ & 83.95 & 32.43 & 1.24 & 0.49 & 31.2 & 84.7 & 68 & 72 & 150 & 13 \\
9 & 54.32 & 50.9 & 1.11 & 0.9 & 28.8 & 75.3 & & & & \\
10 & 38.27 & 68.47 & 1.21 & 0.9 & 30.7 & 75.2 & & & & \\
11 & 23.46 & 79.28 & 1.13 & 0.97 & 29.2 & 73.9 & & & & \\
\hline
\end{tabular}

*cut off scores of the TUG test. $\mathrm{LR}+=$ Likelihood ratio positive LR- = Likelihood ratio negative $\mathrm{PPV}=$ Positive predictive value $\mathrm{NPV}=$ Negative predictive value
True+= Total number of true positive False $+=$ Total number of false positive True- $=$ Total number of true negative False- $=$ Total number of false negative
$32.43 \%$, respectively, for the TUG test in discriminating older adults at risk of fall. Using this TUG test cut off score, $68(84 \%)$ out of 81 older adults who have experienced falls were categorized to be at risk of fall. The cut off score in our study is lower as compared to that in previous studies ranging between 10 and $13.5 \mathrm{~s}$ (Alexander et al. 2012; Rose et al. 2002; Shumway-Cook 2000). Comparably, our study participants were considered younger (60 years and above) to those in previous studies (65 years and above). Other likely reasons may include falls operative definition used in the study.

In addition, if the cut off scores from these previous studies were adapted to our study population, only an estimated of $8(9.8 \%)$ to $31(38.27 \%)$ older adults would have been indicated to have a risk of fall from the 81 who reported to have incidences of falls. This is further supported by the results of the TUG test where it identified a large number of older adults who were at high risk of fall after prospectively observing them over a span of six months.

The TUG cut off score specificity in our study may be considered low, but it is acceptable for use as an early falls screening tool. Moreover, higher sensitivity compared to specificity values are suitable in situations where higher percentage of older adults were allowed to participate in falls prevention programs. Higher sensitivity and lower likelihood ratio for negative (LR-) assist in decreasing false negative results (Wrisley \& Kumar 2010). In reference to this, only 13 out of 305 older adults in our present study were screened to have low fall risk but had a fall incident. In agreement with the call for early fall risk assessment and prevention among older adults as emphasized in the updated NICE (2015) falls quality standards, the cut off values were determined based on the objective of this study, which is to ensure as many as possible older adults to be included in the prevention program, therefore sensitivity value should be high. Whereas, if the objective of the study was to detect older adults with high risk of fall and consequently subject them to another costly and complex diagnosis test, the highest specificity value is needed.

No significant differences were found in GS $(p=0.20)$ and WWT $(p=0.12)$ mean scores between older adults with and without falls. Therefore, it renders itself unsuitable to be used for the purpose of fall risk screening among community dwelling older adults. Similarly, our earlier literature review findings regarding the suitability of GS as a falls screening tool among community dwelling older adults have highlighted the lack of its discriminative and predictive validity (Samah et al.2016). The mean (standard deviation) score for GS in this study is $1.05(0.25) \mathrm{m}$ per second which is within the normal range (from 0.94 to $1.34 \mathrm{~m}$ per second) reported amongst older adults aged between 60 and 99 years (Bohannon \& Andrews 2011). It was also suggested that GS test may be more beneficial in predicting future incidence of falls in older adults with current history of falls rather than without (Viccaro et al. 2011).

The WWT test is a cognitive test with the 'dual task' element and is reported to be used for the purpose of screening risk of fall among older adults with cognitive impairments (Verghese et al. 2002). There is limited literature regarding the WWT test and its cut off point in discriminating between community dwelling older adults who were 'fallers' and 'non-fallers'. Though cut off scores have been established among community dwelling older adults, a direct comparison to that obtained in the current study is not possible as the characteristics and type of 'dual task' executed differ in each study. For example, the study conducted by Beauchet et al. (2008) reported the mean score of the WWT at $0.53 \mathrm{~m}$ per second which differs greatly to that found in this study at $0.77 \mathrm{~m}$ per second. This difference can be explained by the participants in the former study as it involved community dwelling older adults with symptoms of dementia and depression (Beauchet et al. 2008).

Among the limitations of our study is that the findings may not be applicable to older adults who are non-community dwelling such as those who are institutionalised, cognitively impaired and frail due to the exclusion criteria. Our study was also conducted in a single state in Malaysia and may not be generalised to the entire Malaysian community dwelling older adults. However, it is noteworthy that we used multistage random sampling method and prospective falls monitoring.

\section{CONCLUSION}

TUG test was found to be the most apt falls screening tool among our study population. We recommend development of a cohesive falls prevention program with incorporation 
of the TUG test as a screening tool for risk of fall with the eight seconds cut off score for Malaysian community dwelling older adults. However due to its low specificity, older adults found to have high risk of fall should be subjected to further comprehensive assessment in cases where clinical intervention is to be provided.

\section{ACKNOWLEDGMENTS}

The authors would like to thank all participants and LRGS team for their support and assistance rendered in the study. This study is funded using a grant from Ministry of Higher Education, Malaysia via Universiti Kebangsaan Malaysia (LRGS/BU/2012/UKM-UKM/K/01).

\section{REFERENCES}

Alexandre, T.S., Meira, D.M., Rico, N.C. \& Mizuta, S.K. 2012. Accuracy of timed up and go for screening risk of fall among community dwelling elderly. Revista Brasileira de Fisioterapia 16(5): 381-388

Beauchet, O., Annweiler, C., Allali, G., Berrut, G., Hermann, F.R. \& Dubost, V. 2008. Recurrent falls and dual task related decrease in walking speed: Is there a relationship? Journal of the American Geriatrics Society 56(7): 1265-1269.

Bohannon, R.W. \& Andrews, A.W. 2011. Normal walking speed: A descriptive meta-analysis. Physiotherapy 97(3): 182-189.

Borson, S., Scanlan, J.M., Chen, P. \& Ganguli, M. 2003. The mini-cog as a screen for dementia: Validation in a populationbased sample. American Geriatrics Society 51: 1451-1454.

Chang, J.T., Morton, S.C., Rubenstein, L.Z., Mojica, W.A., Maglione, M., Suttorp, M.J., Roth, E.A. \& Shekelle, P.G. 2004. Interventions for the prevention of falls in older adults: Systematic review and meta-analysis of randomized controlled trials. The BMJ 328(7441): 680.

Chiu, A.Y., Au-Yeung, S.S. \& Lo, S.K. 2003. A comparison of four functional tests in discriminating fallers from non-fallers in older people. Disability and Rehabilitation 25(1): 45-50.

Csapo, R., Gormasz, C. \& Baron, R. 2009. Functional performance in community dwelling and institutionalised elderly women. Wiener Klinische Wochenschrit.121(11-12): 383-390.

Dhargave, P. \& Sendhilkumar, R. 2016. Prevalence of risk factors for falls among elderly people living in long term care homes. Journal of Clinical Gerontology and Geriatrics 7(3): 99-103.

Ibrahim, A., Singh, D.K.A. \& Shahar, S. 2017a. 'Timed Up and Go' test: Age, gender and cognitive impairment stratified normative values of older adults. PLoS One 12(10): e0185641.

Ibrahim, A., Singh, D.K.A., Shahar, S. \& Omar, M.A. 2017b. Timed up and go test combined with self-rated multifactorial questionnaire on fall risk and sociodemographic factors predicts falls among community-dwelling older adults better than the timed up and go test on its own. Journal of Multidisciplinary Healthcare 10: 409-416.

Ishimoto, Y., Wada, T., Hirosaki, M., Kasahara, Y., Kimura, Y., Konno, A., Nakatsuka, M., Sakamoto, R., Ishine, M., Okumiya, K., Fujisawa, M., Otsuka, K. \& Matsubayashi, K. 2009. Age and sex significantly influence fall risk in community dwelling elderly people in Japan. Journal of the Geriatrics Society 57(5): 930-932.

Kellogg International Work Group. 1987. The prevention of falls in later life. A report of the Kellogg International Work on the prevention of falls by the elderly. Danish Medical Bull. 34(4): 1-24.

Lam, H.S., Lau, F.W., Chan, G.K. \& Sykes, K. 2010. The validity and reliability of a 6 meter timed walk for the functional assessment of patients with stroke. Physiotherapy Theory and Practice 26(4): 251-256.

Lee, A., Lee, K.W. \& Khang, P. 2013. Preventing falls in the geriatric population. The Permanente Journal 17(4): 37-39.

Lord, S.R., Menz, H.B. \& Tiedemann, A. 2003. A physiological profile approach to fall risk: Assesment and prevention. Physical Therapy 83(3): 237-252.

Masud, T. \& Morris, R.O. 2001 . Epidemiology of falls. Age and Ageing 30(4): 3-7.

Makhlouf, M.M. \& Ayoub,A.I. 2000. Falls among institutionalised elderly in Alexandria. The Journal of the Egyptian Public Health Association 75(5-6): 507-528.

Mathias, S., Nayak, U.S. \& Isaacs, B. 1986. Balance in elderly patients: The get up and go test. Archives of Physical Medicine and Rehabilitation 67(6): 387-389.

NICE. 2015. Falls in Older Adults. National Institute for Care and Health Excellence. Updated: January 2017.

Novaes, R.D., Miranda, A.S. \& Dourado, V.Z. 2011. Usual gait speed assessment in middle-aged and elderly Brazilian subjects. Revista Brasileira de Fisioterapia 15(2): 117-122.

Rizawati, M. \& Mas Ayu, S. 2008. Home environment and fall at home among the elderly in Masjid Tanah Province. Journal of Health and Translational Medicine 11(2): 72-82.

Rose, D.J., Jones, C.J. \& Lucchese, N. 2002. Predicting the probability of falls in community residing older adults using the 8-foot up and go: A new measure of functional mobility. Journal of Aging and Physical Activity 20: 466-475.

Sahin, H. \& Erkai, S. 2016. Evaluation of home accidents and fall behaviors of elderly. Turkish Journal of Geriatrics 19(3): 195-202.

Samah,Z.A., Nordin, N.A.M., Shahar, S. \& Singh, D.K.A. 2016 Can gait speed test be used as a fall riskscreening tool in community dwelling older adults? A review. Polish Annals of Medicine 23(1): 61-67.

Shumway-Cook,A., Brauer, S.\& Woollacott, M. 2000. Research report predicting the probability for falls in communitydwelling older adults using the timed up and go test. Journal of the American Physical Therapy 80: 896-903.

Singh, D.K.A., Pillai, S.G.K., Tan, S.T., Tai, C.C. \& Shahar, S. 2015. Association between physiological fall risk and physical performance tests among community-dwelling older adults. Clin. Interv. Aging 10: 1319-1326.

Shahar, S., Omar, A., Vanoh, D., Hamid, T.A., Mukari, S.Z.M., CheDin, N., Rajab, N., Mohammed, Z., Ibrahim, R., Loo, W.H., Meramat, A., Kamaruddin, M.Z.A., Bagat, M.F. \& Razali, R. 2016. Approaches in methodology for populationbased longitudinal study on neuroprotective model for healthy longevity (TUA) among Malaysian older adults. Aging Clin . Exp. Res. 28(6): 1089-1104.

Verghese, J., Buschke, H., Viola, L., Katz, M., Hall, C., Kuslanky, G. \& Lipton, R. 2002. Validity of divided attention tasks in predicting falls in older individuals: A preliminary study. Journal of the American Geriatrics Society 50(9): 1572-1576.

Viccaro, L.J., Perera, S. \& Studenski, S.A. 2011. Is timed up and go better than gait speed in predicting health, function, and falls in older adults? Journal of the American Geriatrics Society 59(5): 887-892.

Whitney, J.C., Lord, S.R. \& Close, J.C.T. 2005. Streamlining assessment and intervention in a falls clinic using the Timed 
Up and Go test and physiological profile assessment. Journal of Age and Ageing 34(6): 567-571.

WHO. 2008. Fact Sheet: Falls. World Health Organisation. Reviewed January 2018.

Williams, J.S., Kowal, P., Hestekin, H., O’Driscoll, T., Peltzer, K., Yawson, A., Biritwum, R., Maxmova, T., Rodriguez, A.S., Espinoza, B.M., Wu, F., Arokiasamy, P., Chatterji, S. \& SAGE Collaborators. 2015. Prevalence, risk factors and disability associated with fall-related injury in older adults in low and middle-income countries: Results from the WHO Study on Global Aging and Adult Health (SAGE). BMC Medicine 13: 147.

Wrisley, D.M. \& Kumar, N.A. 2010. Functional gait assessment: Concurrent, discriminative and predictive validity in community dwelling older adults. Physical Therapy 90(5): 761-773.

\section{Zunaidah Abu Samah}

Department of Medical Rehabilitation Services

UKM Medical Centre

Jalan Yaa'cob Latiff, Bandar Tun Razak

56000 Cheras, Kuala Lumpur, Federal Territory

Malaysia

Devinder Kaur Ajit Singh*, Resshaya Roobini Murukesu \& Nor Azlin Mohd Nordin

Physiotherapy Programme

Centre for Rehabilitation and Special Needs

Faculty of Health Sciences

Universiti Kebangsaan Malaysia

Jalan Raja Muda Abd Aziz

50300 Kuala Lumpur, Federal Territory

Malaysia
Suzana Shahar

Centre for Healthy Aging and Wellness

Faculty of Health Sciences

Universiti Kebangsaan Malaysia

Jalan Raja Muda Abd Aziz

50300 Kuala Lumpur, Federal Territory

Malaysia

Mohd Azahadi Omar

Centre for Burden of Disease Research

Institute for Public Health

Ministry of Health

Jalan Bangsar, Federal Hill

50590 Kuala Lumpur, Federal Territory

Malaysia

Chin Ai-Vyrn

Ageing and Age-Associated Disorders Research Group

Division of Geriatric Medicine

Faculty of Medicine

University Malaya

50603 Kuala Lumpur, Federal Territory

Malaysia

*Corresponding author; email: devinder@ukm.edu.my

Received: 27 March 2018

Accepted: 6 July 2018 